\title{
Serum Lipids and Lipoproteins at Birth in a Biracial Population: The Bogalusa Heart Study
}

\author{
RALPH R. FRERICHS, SATHANUR R. SRINIVASAN, LARRY S. WEBBER, MARC C. RIETH, AND \\ GERALD S. BERENSON ${ }^{(33)}$ \\ Departments of Public Health and Preventive Medicine (R.R.F.) and Medicine (S.R.S., L.S.W., M.C.R., G.S.B.), \\ Louisiana State University Medical Center, New Orleans, Louisiana, USA
}

\section{Summary}

The lipid profile, total cholesterol, triglycerides, and lipoproteins $(\beta-$, pre- $\beta-$, and $\alpha-)$ of cord blood, is presented for 419 black and white infants (94\% of the eligible population) born during an 18month period in Bogalusa, Louisiana. At birth, white neonates of both sexes had higher average levels than black neonates of total cholesterol and $\beta$-lipoproteins. White girls among the four racesex groups had the highest cord blood levels of total cholesterol, $\beta$-lipoproteins, and $\alpha$-lipoproteins. Neither stress at delivery, birthweight, socioeconomic status, nor season of the year had an observable effect on any of the lipid or lipoprotein levels. The magnitude and direction of the relationships between the respective lipids and lipoproteins in cord blood were similar to those we have observed in preschool and school-aged children in the same community. Total cholesterol was highly correlated with both $\beta$ and $\alpha$-lipoproteins; triglycerides were correlated with pre- $\beta$-lipoproteins but inversely with $\alpha$-lipoproteins. These observations suggest that basic biochemical relationships are already established at birth.

\section{Speculation}

The lipid and lipoprotein levels in cord blood provide useful baseline data for evaluating the evolution of lipoprotein profiles in children. By elucidating those factors which serve as determinants of lipids and lipoproteins in cord blood, we may come closer to understanding the lipid regulatory mechanisms in the general population.

Elevated levels of blood lipids are clearly associated with coronary artery disease in adult populations $(18,19)$. However, the extensive presence of fatty streaks and the gradual formation of fibrous plaques during the pediatric years suggest that the pathologic precursors of coronary artery disease originate during childhood $(17,28)$. We have shown previously that lipid and lipoprotein levels of children by age 3 years already approach those of early adulthood $(3,4,11,26,27)$. Furthermore, differences in lipid and lipoprotein levels between blacks and whites were noted in children $(11,27)$ as well as adults (32), suggesting the possible influence of genetic factors. In newborns, however, there are diverging reports concerning sex or genetic differences in lipids and lipoproteins $(5,8,12,13,25)$.

Although the study of cord blood cholesterol has been suggested to aid in the diagnosis of a genetic form of hypercholesterolemia $(13,31)$, it is apparent that further studies of blood lipids and lipoproteins are indicated. The present study reports the serum lipid and lipoprotein profile at birth from a total population of both black and white children born in a geographically defined community.

\section{MATERIALS AND METHODS}

\author{
POPULATION SAMPLE
}

Of the 447 eligible children ( $38.5 \%$ black, $61.5 \%$ white) born to Ward 4 (Bogalusa) Louisiana residents between January 1, 1974 and June $30,1975,98.4 \%(440)$ consented to participate in the study (100\% of the black infants, $97.5 \%$ of the white infants). The eligible population was subsequently verified using the county birth register for Washington Parish, Louisiana.

\section{COLLECTION OF BLOOD SPECIMENS}

After the infant was delivered but with the placenta still in the uterus, the umbilical cord was double clamped $5-8 \mathrm{~cm}$ from the umbilicus and subsequently severed between the two clamps. The hemostat was removed from the placental side of the cord, a small amount of the flowing blood was discarded and approximately 10 $\mathrm{ml}$ of cord blood was collected from the placental side in a sterile medical glass. The blood was then transferred to a collecting tube containing antibacterial thimerosal (Aldrich Chemical Co., Milwaukee, WI) and refrigerated at $4^{\circ}$. Within $18 \mathrm{hr}$, the blood was centrifuged and the serum was packaged with cold packs and sent to the New Orleans Specialized Center of Research-Arteriosclerosis (SCOR-A) Lipid Laboratory where it was immediately refrigerated at $4^{\circ}$ prior to analysis on the following day. Blood samples were not obtained or data were not available from 21 $(4.7 \%)$ of the infants, resulting in a complete lipid and lipoprotein analysis on $419(93.7 \%)$ newborns.

\section{SERUM LIPID AND LIPOPROTEIN ANALYSIS}

Serum cholesterol and triglycerides were determined simultaneously in a Technicon AutoAnalyzer 11 in the Core Laboratory of SCOR-A according to the protocol developed by Lipid Research Clinics in collaboration with the Center for Disease Control, Atlanta, GA (9). A serum calibrator provided by the CDC was used to convert the cholesterol value obtained by an AutoAnalyzer 11 to the reference standard method of Abell $e t$ al. (1). The Core Lipid Laboratory has been designated "standardized" by the CDC and currently is in the surveillance phase of the quality control program.

The serum $\beta$-, pre- $\beta$ - and $\alpha$-lipoprotein levels were measured by a combination of heparin- $\mathrm{Ca}^{++}$precipitation and agar-agarose gel electrophoresis methods (26). A detailed description of the lipoprotein method was reported elsewhere, including its application in the study of 3182 school-aged children of the Bogalusa community (27). As in the previous study, direct determination of cholesterol in the $\beta$ - and pre- $\beta$-lipoprotein fractions (obtained by heparin-Ca ${ }^{++}$precipitation) was related to the $\beta+$ pre- $\beta$-lipoprotein index (turbidity measured at $600 \mathrm{~nm}$ ) in $25 \%$ of the randomly assigned serum samples. The two variables correlated highly ( $r$ 
Table 1. Blind duplicate analysis for serum lipids and lipoproteins of newborns, January 1974 to June 1975

\begin{tabular}{|c|c|c|c|c|c|c|c|}
\hline \multirow[b]{2}{*}{ Cord blood variable } & \multirow[b]{2}{*}{ No. of pairs } & \multicolumn{2}{|c|}{ Mean } & \multirow[b]{2}{*}{$\begin{array}{c}\text { Mean difference } \\
(\mathrm{mg} / \mathrm{dl})\end{array}$} & \multirow[b]{2}{*}{$\begin{array}{l}\text { Mean of abso- } \\
\text { lute differences } \\
(\mathrm{mg} / \mathrm{dl})\end{array}$} & \multicolumn{2}{|c|}{ Measurement error } \\
\hline & & $\begin{array}{l}\text { Original } \\
(\mathrm{mg} / \mathrm{dl})\end{array}$ & $\begin{array}{l}\text { Blind duplicate } \\
(\mathrm{mg} / \mathrm{dl})\end{array}$ & & & $\begin{array}{c}\mathrm{SD} \\
(\mathrm{mg} / \mathrm{dl})\end{array}$ & $\begin{array}{c}\text { Coeff. of vari- } \\
\text { ation } \\
\%\end{array}$ \\
\hline Total cholesterol & 31 & 69.5 & 68.6 & 0.94 & 1.26 & 1.13 & 1.63 \\
\hline Triglycerides & 31 & 40.6 & 38.9 & 1.71 & 5.00 & 4.46 & 11.22 \\
\hline$\beta$-Lipoprotein & 29 & 67.2 & 64.7 & 2.45 & 5.39 & 5.98 & 9.07 \\
\hline Pre- $\beta$-lipoprotein & 29 & 15.0 & 18.8 & -3.77 & 5.17 & 8.42 & 49.72 \\
\hline$\alpha$-Lipoprotein & 31 & 200.5 & 196.7 & 3.80 & 14.58 & 13.18 & 6.64 \\
\hline
\end{tabular}

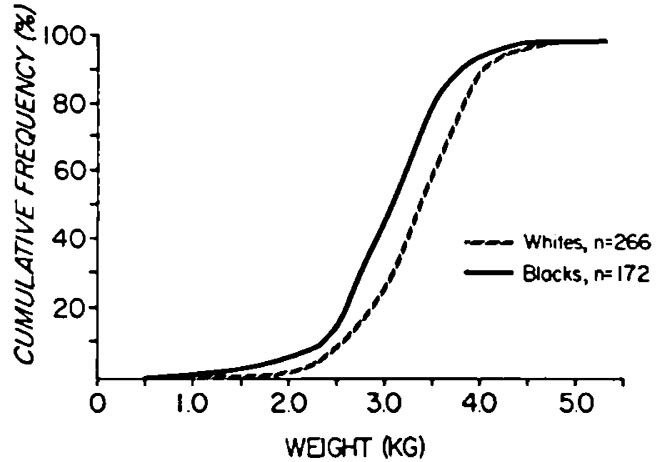

Fig. I. Cumulative frequency distribution for weight at birth of black and white Bogalusa newborns.

$=0.98$ ) and a factor of 451 was obtained by constructing a regression line through the origin. The serum $\beta+$ pre- $\beta$-lipoprotein cholesterol was reported for the cord blood samples using the indirect method $(\beta+$ pre- $\beta$-lipoprotein cholesterol $=451 \times \beta+$ pre- $\beta$-lipoprotein index). The difference between serum total cholesterol and $\beta+$ pre- $\beta$-lipoprotein cholesterol was considered as $\alpha$-lipoprotein cholesterol.

Since cord blood has low lipoprotein levels, the sera $(0.5 \mathrm{ml})$ was mixed with $0.1 \mathrm{~g}$ Sephadex G-25 (Pharmacia, Uppsala, Sweden) and centrifuged and the supernatant-enriched lipoprotein was used for agar-agarose gel electrophoresis. Serum $\beta$ - and pre$\beta$-lipoprotein concentrations were estimated from the densitometric ratio of $\beta$ - to pre- $\beta$-lipoprotein, $\beta+$ pre- $\beta$-lipoprotein cholesterol content, and the reported fractional cholesterol content of these lipoprotein molecules (26); similarly, $\alpha$-lipoprotein levels were obtained by multiplying $\alpha$-lipoprotein cholesterol by a factor of 5.9 (26). The lipoprotein levels (milligrams per $\mathrm{dl}$ ) can be easily converted back into the corresponding lipoprotein cholesterol (milligrams per $\mathrm{dl}$ ) values as follows: $\beta$-lipoprotein cholesterol $=$ $\beta$-lipoprotein $\times 0.469$; pre- $\beta$-lipoprotein cholesterol $=$ pre- $\beta$-lipoprotein $\times 0.222 ; \alpha$-lipoprotein $\times 0.170$.

Serum lipoprotein cholesterol levels were determined independently by the Lipid Research Laboratory, Mayo Clinic (Rochester, $\mathrm{MN}$ ) which uses a combination of ultracentrifugation and precipitation methods (27); analysis of 32 serum samples, including blind duplicates, revealed no statistically significant differences (paired $t$-test) between the two methods. The validity of lipoprotein measurements was also established by comparisons of our results with those obtained by analytic ultracentrifugation (4); both sets of results were in agreement with somewhat better reproducibility using the method described above.

\section{MEASUREMENT ERRORS}

As in our previous studies, approximately $7 \%$ of the sera was selected in a random manner and split into duplicate samples for assessment of lipid and lipoprotein measurement errors (11, 27). Both new names and new identification numbers were placed on the duplicate samples to insure blind analyses through all subsequent stages of laboratory and data analyses. The measurement errors for the serum variables are given in Table 1 and represent the errors associated both with laboratory processing and analysis of the samples, including transcription, editing, and computer processing of the final data.

\section{MATERNAL AND DELIVERY FACTORS}

Information was abstracted from the hospital charts within a few weeks of birth by a trained registered nurse for various factors which related to the delivery. No attempt was made to train the attending obstetrician in reporting of observations at birth. All but 2 of the $\mathbf{4 4 0}$ children were delivered in one of two hospitals in Bogalusa (one is state operated and is used primarily by charity and by Medicaid recipients; one is private). Delivery factors included the type of delivery (normal, cesarean, other), and the presence or absence of fetal anoxia, prolapsed cord, premature separation of the placenta ( $>20$ weeks of gestation), prolonged labor $(>20 \mathrm{hr})$, or an abnormal presentation. In addition, data were abstracted on the 1-min Apgar score and any indication of respiratory distress, congenital heart disease, or erythroblastosis fetalis.

\section{STATISTICAL ANALYSIS}

Racial and sex differences among the means for the various lipids and lipoproteins and birthweight were tested using a $2 \times 2$ factorial analysis of variance.

Racial differences in the Pearson product-moment correlation coefficients between serum lipids and lipoproteins were tested after transforming the correlation coefficients to a quantity, $z$, which is distributed almost normally with SE (24): $\sigma_{2}=$ $1 / \sqrt{n-3}$.

\section{RESULTS}

\section{CUMULATIVE FREQUENCY DISTRIBUTION OF WEIGHT, SERUM LIPIDS, AND LIPOPROTEINS}

As observed in Figures 1 and 2, white children at birth when compared to blacks tended to weigh more and have higher serum levels of total cholesterol, triglycerides, $\beta$-lipoprotein, and $\alpha$-lipoprotein. No racial difference was observed in levels of pre- $\beta$ lipoprotein. Ninety percent of all white infants weighed between $2353 \mathrm{~g}$ (5th percentile) and $4186 \mathrm{~g}$ (95th percentile), whereas for black newborns, the 5 th and 95 th percentiles were $1962 \mathrm{~g}$ and $3989 \mathrm{~g}$, respectively. For all children the 5 th and 95 th percentiles were for total cholesterol $42 \mathrm{mg} / \mathrm{dl}$ and $103 \mathrm{mg} / \mathrm{dl}$, for triglycerides $14 \mathrm{mg} / \mathrm{dl}$ and $84 \mathrm{mg} / \mathrm{dl}$, for $\beta$-lipoprotein $36.3 \mathrm{mg} / \mathrm{dl}$ and 106.0 $\mathrm{mg} / \mathrm{dl}$ ( $\beta$-lipoprotein cholesterol, $17.0 \mathrm{mg} / \mathrm{dl}$ and $49.7 \mathrm{mg} / \mathrm{dl}$ ), for pre- $\beta$-lipoprotein $2.6 \mathrm{mg} / \mathrm{dl}$ and $52.3 \mathrm{mg} / \mathrm{dl}$ (pre- $\beta$-lipoprotein cholesterol, $0.6 \mathrm{mg} / \mathrm{dl}$ and $11.6 \mathrm{mg} / \mathrm{dl}$ ), and for $\alpha$-lipoprotein 74.6 $\mathrm{mg} / \mathrm{dl}$ and $355.4 \mathrm{mg} / \mathrm{dl}(\alpha$-lipoprotein cholesterol, $12.7 \mathrm{mg} / \mathrm{dl}$ and $60.2 \mathrm{mg} / \mathrm{dl})$.

\section{MEAN WEIGHT, SERUM LIPID. AND LIPOPROTEIN LEVELS}

The means and SD for birthweight and the serum lipids and lipoproteins are shown in Table 2 . The average birthweight for all 
infants was $3228 \mathrm{~g}$ with whites weighing more than blacks. White boys were significantly heavier than the other three race-sex groups. Mean levels of both total cholesterol and $\beta$-lipoprotein were significantly greater in whites of both sexes than in blacks. White girls had the highest average levels among the four race-sex groups of total cholesterol, $\beta$-lipoproteins, and $\alpha$-lipoprotein. With the exception of pre- $\beta$-lipoproteins, black boys consistently had the lowest observable levels of all the cord blood variables. For all

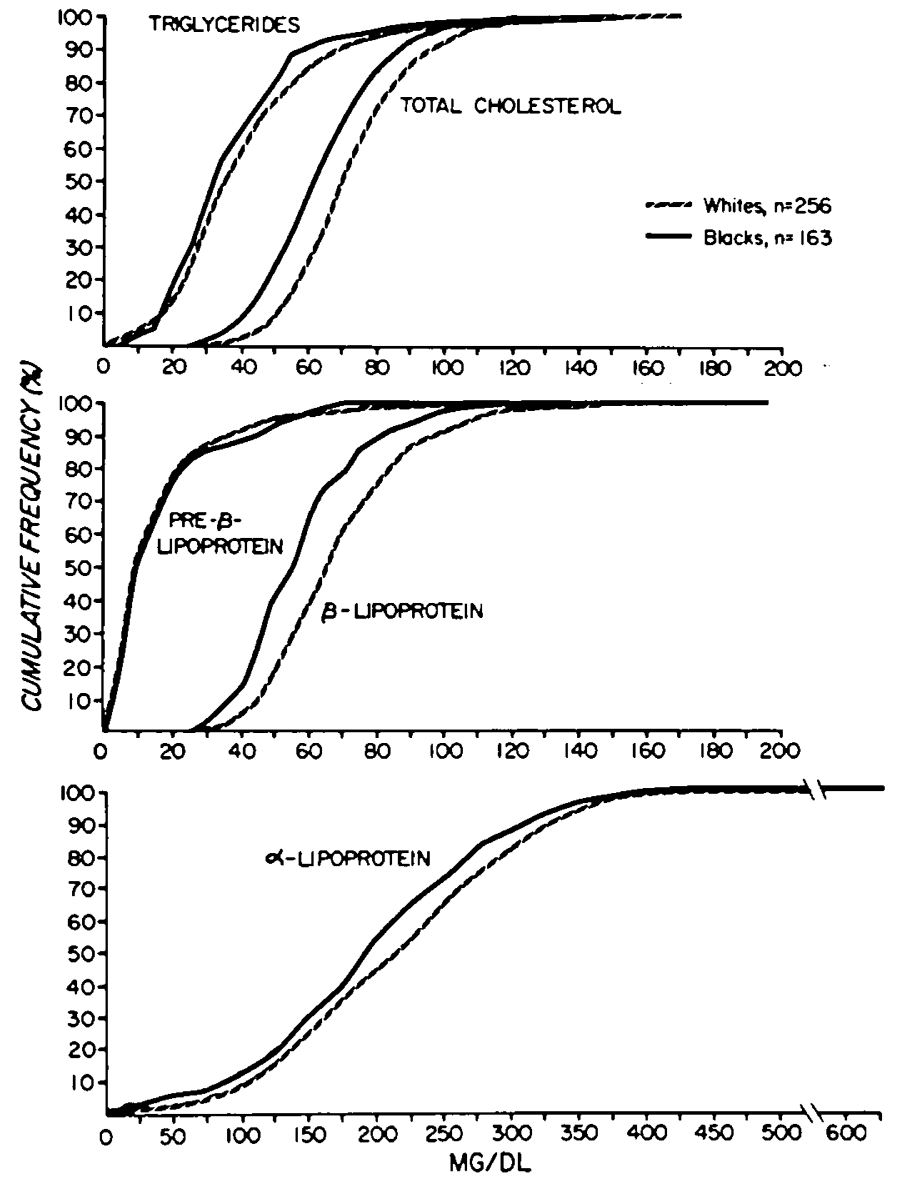

Fig. 2. Cumulative frequency distributions for lipids and lipoproteins at birth of black and white Bogalusa newborns. children combined, $44 \%$ of the total cholesterol was found in $\beta$ lipoproteins $(30.4 \pm 10.3 \mathrm{mg} / \mathrm{dl}), 5 \%$ in pre- $\beta$-lipoproteins $(3.6 \pm$ $4.1 \mathrm{mg} / \mathrm{dl}$ ), and $51 \%$ in $\alpha$-lipoproteins $(35.5 \pm 14.8 \mathrm{mg} / \mathrm{dl})$. Individual variability was marked.

\section{INTERRELATIONSHIP AMONG SERUM LIPIDS AND LIPOPROTEINS}

The interrelationships among the serum lipids and lipoproteins are shown by race in Table 3 . Total cholesterol was highly correlated with both $\beta$ - and $\alpha$-lipoproteins, the two major carriers of cholesterol in the blood. Triglycerides, although significantly correlated with $\beta$-lipoproteins, were highly correlated with the major carrier of triglycerides in the sera, namely pre- $\beta$-lipoproteins. The association between triglycerides and pre- $\beta$-lipoproteins was significantly greater in whites than in blacks with over $67 \%$ $\left(r^{2}\right)$ of the variability in pre- $\beta$-lipoprotein levels explained by knowledge of the respective triglyceride levels. $\alpha$-Lipoproteins were negatively correlated with both triglycerides and pre- $\beta$-lipoproteins. The magnitude of the respective correlations are similar to those which we reported previously for preschool (3) and school-aged children (27) in the same community, although total cholesterol was more highly correlated with $\alpha$-lipoprotein than in the studies of children.

That the positive relationships of total cholesterol with both $\beta$ -

Table 3. Pearson product-moment correlation coefficient between serum lipids and lipoproteins by race in 252 white and 160 black newborns, January 1974 to June 1975

\begin{tabular}{lcccc}
\hline & $\begin{array}{c}\text { Triglyc- } \\
\text { erides }\end{array}$ & $\begin{array}{c}\beta \text {-Lipo- } \\
\text { protein }\end{array}$ & $\begin{array}{c}\text { Pre- } \beta \text {-lipo- } \\
\text { protein }\end{array}$ & $\begin{array}{c}\alpha \text {-Lipopro- } \\
\text { tein }\end{array}$ \\
\hline $\begin{array}{l}\text { Total cholesterol } \\
\text { Whites }\end{array}$ & 0.110 & $0.641^{1}$ & 0.068 & $0.729^{1}$ \\
$\quad$ Blacks & 0.070 & $0.641^{1}$ & 0.017 & $0.804^{1}$ \\
$\begin{array}{l}\text { Triglycerides } \\
\text { Whites }\end{array}$ & & & & \\
$\quad$ Blacks & & $0.435^{1}$ & $0.820^{1,2}$ & $-0.412^{1}$ \\
$\beta$-Lipoprotein & & $0.391^{1}$ & $0.696^{1}$ & $-0.347^{1}$ \\
$\quad$ Whites & & & & \\
$\quad$ Blacks & & & $0.270^{1}$ & -0.012 \\
Pre- $\beta$-lipoprotein & & & & 0.139 \\
$\quad$ Whites & & & & \\
Blacks & & & & $-0.399^{1}$ \\
\hline
\end{tabular}

${ }^{1}$ Levels of significance: correlation coefficient different from zero, $P<$ 0.001 .

${ }^{2}$ Significant racial difference in correlation coefficients, $P<0.01$.

Table 2. Birthweight, serum lipids and lipoproteins ${ }^{1}$ (mean \pm 1 SD) of newborns, by race and sex, January 1974 to June 1975

\begin{tabular}{|c|c|c|c|c|c|c|c|c|c|c|}
\hline \multirow[b]{3}{*}{ Variable } & \multicolumn{4}{|c|}{ White } & \multicolumn{4}{|c|}{ Black } & \multirow{2}{*}{\multicolumn{2}{|c|}{ All children }} \\
\hline & \multicolumn{2}{|r|}{ Boys } & \multicolumn{2}{|r|}{ Girls } & \multicolumn{2}{|r|}{ Boys } & \multicolumn{2}{|r|}{ Girls } & & \\
\hline & $\mathbf{n}$ & $\bar{\chi} \pm \mathrm{SD}$ & $n$ & $\bar{\chi} \pm \mathrm{SD}$ & $n$ & $\bar{\chi} \pm \mathrm{SD}$ & $n$ & $\bar{\chi} \pm \mathrm{SD}$ & $n$ & $\bar{\chi} \pm \mathrm{SD}$ \\
\hline Birthweight (kg) & 133 & $3.44 \pm 0.57^{2,3}$ & 133 & $3.24 \pm 0.55^{4}$ & 84 & $3.06 \pm 0.69$ & 88 & $3.04 \pm 0.56$ & 438 & $3.23 \pm 0.61$ \\
\hline Total cholesterol $(\mathrm{mg} / \mathrm{dl})$ & 129 & $70 \pm 17^{5}$ & 127 & $76 \pm 17^{3,6}$ & 79 & $62 \pm 20$ & 84 & $66 \pm 17$ & 419 & $70 \pm 18$ \\
\hline Triglycerides (mg/dl) & 129 & $44 \pm 26$ & 127 & $39 \pm 20$ & 79 & $37 \pm 19$ & 84 & $38 \pm 22$ & 419 & $40 \pm 22$ \\
\hline$\beta$-Lipoprotein (mg/dl) & 127 & $\begin{array}{c}68 \pm 22^{3} \\
(32 \pm 11)^{1}\end{array}$ & 125 & $\begin{array}{c}70 \pm 21^{5} \\
(33 \pm 10)\end{array}$ & 78 & $\begin{array}{c}54 \pm 18 \\
(25 \pm 8)\end{array}$ & 82 & $\begin{array}{c}62 \pm 23^{6} \\
(29 \pm 11)\end{array}$ & 412 & $\begin{array}{c}65 \pm 22 \\
(30 \pm 10)\end{array}$ \\
\hline Pre- $\beta$-lipoprotein (mg/dl) & 127 & $\begin{array}{c}18 \pm 21 \\
(4 \pm 5)\end{array}$ & 125 & $\begin{array}{l}14 \pm 16 \\
(3 \pm 4)\end{array}$ & 78 & $\begin{array}{l}16 \pm 16 \\
(4 \pm 4)\end{array}$ & 82 & $\begin{array}{l}16 \pm 19 \\
(4 \pm 4)\end{array}$ & 412 & $\begin{array}{c}16 \pm 19 \\
(4 \pm 4)\end{array}$ \\
\hline$\alpha$-Lipoprotein (mg/dl) & 129 & $\begin{array}{c}200 \pm 86 \\
(34 \pm 15)\end{array}$ & 126 & $\begin{array}{c}234 \pm 83^{2,5} \\
(40 \pm 14)\end{array}$ & 79 & $\begin{array}{l}196 \pm 101 \\
(33 \pm 17) \\
\end{array}$ & 83 & $\begin{array}{c}201 \pm 77 \\
(34 \pm 13) \\
\end{array}$ & 417 & $\begin{array}{l}210 \pm 88 \\
(36 \pm 15) \\
\end{array}$ \\
\hline
\end{tabular}

\footnotetext{
${ }^{2}$ Sex differences significant at $P<0.05$ ( $F$-test).

${ }^{3}$ Race differences significant at $P<0.001$ ( $F$-test).

${ }^{4}$ Race differences significant at $P<0.05$ ( $F$-test)

${ }^{5}$ Race differences significant at $P<0.01$ ( $F$-test).

${ }^{6}$ Sex differences significant at $P<0.05$ ( $F$-test).
}

${ }^{1}$ Corresponding lipoprotein cholesterol values are given in parentheses. 
lipoprotein and $\alpha$-lipoprotein should be considered in evaluating hypercholesterolemia becomes clear when viewing those neonates with serum values at or above the 95 th percentile. Of the 22 newborns with hypercholesterolemia based on the 95 th percentile level ( $\geq 103 \mathrm{mg} / \mathrm{dl}), 7$ (32\%) also exhibited hyperbetalipoproteinemia $(\beta$-lipoprotein cholesterol $\geq 49.7 \mathrm{mg} / \mathrm{dl})$, whereas $10(45 \%)$ were hyperalphalipoproteinemic $(\alpha$-lipoprotein cholesterol $\geq 60.2$ $\mathrm{mg} / \mathrm{dl}$ ). On the other hand, of the 20 neonates with $\beta$-lipoprotein levels at or above the 95 th percentile, $13(65 \%)$ had serum cholesterol values which were below the 95 th percentile.

\section{RELATIONSHIP BETWEEN WEIGHT AND SERUM LIPIDS AND LIPO-} PROTEINS

Within each race, all of the correlation coefficients between birthweight and the respective serum variables were of a low order and none were statistically significant. The effect of birthweight on the serum variables was further analyzed by comparing within race the mean levels of serum lipids and lipoproteins in each of three birthweight categories $(<2.5 \mathrm{~kg}, 2.5-3.5 \mathrm{~kg}$, and $>3.5 \mathrm{~kg})$. There were no statistically significant differences within either black or white neonates in any of the lipid or lipoprotein categories. Within each weight category, whites persistently had higher levels than blacks of total cholesterol, $\beta$-lipoproteins, and $\alpha$-lipoproteins, indicating that the previously mentioned racial differences in the cord blood variables exist independent of birthweight.

When analyzing the mean levels within five birthweight categories (<1.8 kg, 1.8-2.5 kg, $2.5-3.5 \mathrm{~kg}, 3.5-4.0 \mathrm{~kg}$, and $\geq 4.0 \mathrm{~kg}$ ), we observed no significant differences within the white neonates but some statistically significant differences were apparent in the black newborns, although of a low and inconsistent order. For instance, in blacks weighing less than $1.8 \mathrm{~kg}$ the mean triglyceride levels were significantly higher $(P<0.05)$ and mean $\alpha$-lipoprotein levels significantly lower $(P<0.05)$ than in black infants with a birthweight between 1.8 and $2.5 \mathrm{~kg}$, although neither of the serum variables in the lowest birthweight group differed significantly from the mean levels within the remaining three weight categories.

\section{EFFECTS OF FACTORS AT TIME OF DELIVERY, SOCIOECONOMIC} STATUS, AND SEASON

After adjusting for the effects of race and sex, we compared the mean levels of the serum lipids and lipoproteins with respect to the type of delivery, stress at delivery, and the 1-min Apgar score. Whether the delivery was normal or abnormal (including cesarean) had no discernible effect on the lipid or lipoprotein values. In addition, as shown in Table 4 , no statistically significant differences were found in the mean levels of birthweight or the serum variables between those who had some stressful event at birth (fetal anoxia, prolapsed cord, premature separation of placenta, prolonged labor, or abnormal presentation) and those who did not. Only 342 of the 419 infants with cord blood data (82\%) had an Apgar score. After dividing the population into three Apgar categories (1-7, 8, 9-10), we found no significant differences among the three groups in mean levels of any of the serum variables.

Other investigators have recently reported a higher prevalence of maternal-fetal problems in hypertriglyceridemic newborns when compared with a normal control group $(2,7,30)$. When we compared the 42 Bogalusa newborns with triglyceride levels at or above the race-sex-specific 90 th percentile with the remaining group ( $n=377$ ), we found no significant difference in the proportions of any factors associated with perinatal stress (fetal anoxia, prolapsed cord, premature separation of the placenta, prolonged labor, abnormal presentation, and Apgar score $\leq 6)$. Of the 42 hypertriglyceridemic newborns, only $34(81 \%)$ were given an Apgar score and only one score was equal to or less than 6. This proportion is almost equal to that found in the remaining 377 newborns for whom $308(82 \%)$ received an Apgar score of which $17(6 \%)$ were equal to or less than 6.

The effect that socioeconomic factors have on cord blood variables was indirectly analyzed by comparing the mean values by race of children born in each of the two Bogalusa hospitals (Table 5). One hospital is operated by the state of Louisiana and serves the indigent population while the other is private and requires a fee for service. Of all cord bloods collected at the state hospital, $66 \%$ were from black newborns and $34 \%$ were from white newborns; at the private hospital, the racial division was $19 \%$ black newborns and $81 \%$ white newborns.

At both hospitals, white neonates weighed significantly more than black neonates, although in both races those born at the private hospital weighed significantly more than those born at the public hospital. The average birthweight of blacks delivered at the private hospital was almost identical to the average birthweight of whites at the public hospital, suggesting that both socioeconomic and genetic factors influence the weight at birth.

In contrast, the previously observed racial differences in levels of the cord blood variables were not explained by socioeconomic differences between black and white neonates. There were no significant differences within each race between the two hospitals in any of the mean levels of the serum variables although racial differences in total cholesterol and $\beta$-lipoproteins were apparent within each of the two hospitals.

Since cord bloods were collected over an 18-month period, we were able to determine whether the season of the year had any effect on lipid levels. Based on an analysis of variance comparing mean values on four seasons of the year, we found no significant differences in any of the serum variables.

Table 4. Serum lipids, lipoproteins ${ }^{1}$ and birthweight (mean \pm 1 SD) by stress category for 440 newborns, January 1974 to June 1975

\begin{tabular}{|c|c|c|c|c|c|c|c|c|}
\hline Variable & \multicolumn{4}{|c|}{ Whites } & \multicolumn{4}{|c|}{ Blacks } \\
\hline Total cholesterol & 43 & $74 \pm 17$ & 212 & $73 \pm 18$ & 15 & $63 \pm 15$ & 148 & $65 \pm 19$ \\
\hline Triglycerides & 43 & $42 \pm 26$ & 212 & $41 \pm 23$ & 15 & $40 \pm 30$ & 148 & $37 \pm 19$ \\
\hline Pre- $\beta$-lipoprotein & 42 & $\begin{array}{l}19 \pm 22 \\
(4 \pm 5)\end{array}$ & 209 & $\begin{array}{l}16 \pm 19 \\
(4 \pm 4)\end{array}$ & 14 & $\begin{array}{l}16 \pm 18 \\
(3 \pm 4)\end{array}$ & 146 & $\begin{array}{l}16 \pm 18 \\
(4 \pm 4)\end{array}$ \\
\hline$\alpha$-Lipoprotein & 43 & $\begin{array}{c}214 \pm 94 \\
(36 \pm 16)\end{array}$ & 211 & $\begin{array}{l}217 \pm 85 \\
(37 \pm 14)\end{array}$ & 15 & $\begin{array}{l}183 \pm 83 \\
(31 \pm 14)\end{array}$ & 147 & $\begin{array}{l}200 \pm 90 \\
(34 \pm 15)\end{array}$ \\
\hline Birthweight (kg) & 43 & $3.34 \pm 0.74$ & 222 & $3.35 \pm 0.53$ & 18 & $3.17 \pm 1.21$ & 154 & $3.04 \pm 0.53$ \\
\hline
\end{tabular}

\footnotetext{
${ }^{1}$ Corresponding lipoprotein cholesterol values are given in parentheses.

${ }^{2}$ Stress is defined as present if any of the following conditions are present: fetal anoxia, prolonged labor, prolapsed cord, abnormal presentation, premature separation of placenta.
} 
Table 5. Serum lipids, lipoproteins, and birthweight of newborns (mean \pm 1 SD) by race and hospital, January 1974 to June 1975

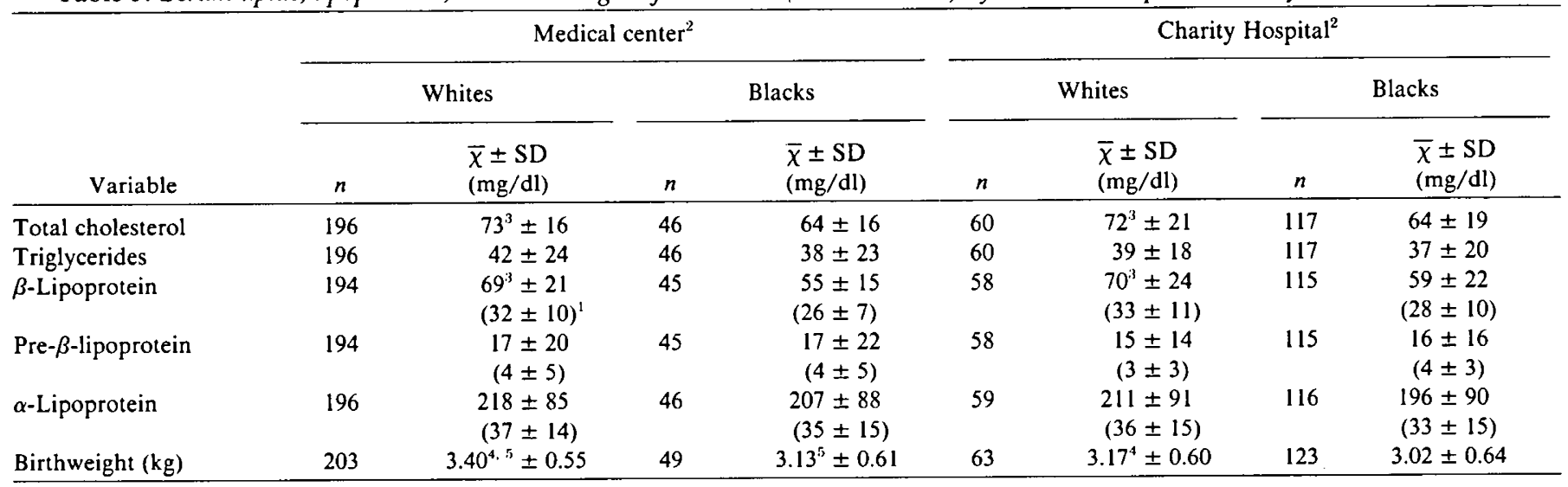

' Corresponding lipoprotein cholesterol values are given in parentheses.

${ }^{2}$ Medical Center, medium to high income patients; Charity Hospital, primarily low income patients.

${ }^{3}$ Significant race effect, $P<0.0001$.

${ }^{4}$ Significant race effect, $P<0.01$.

'Significant hospital effect, $P<0.01$.

\section{DISCUSSION}

Although there are numerous studies of cord blood lipids, little comparative information is available on racial differences or from a well defined community. In a recent preliminary report, Glueck et al. (12) presented lipid data for 117 black and white neonates. Our observation that white females at birth had the highest levels of both total cholesterol and $\alpha$-lipoprotein cholesterol was also noted by these investigators but the mean differences in their study were not statistically significant. However, their study was hospital based rather than community based (two hospitals in Cincinnati, $\mathrm{OH}$ ) and therefore may not be comparable.

The average concentrations of the cord blood variables in Bogalusa newborns are in general agreement with those reported by other investigators. For instance, in Bogalusa the mean level of total cholesterol was $70 \mathrm{mg} / \mathrm{dl}$ while the range reported by others was from $60-82 \mathrm{mg} / \mathrm{dl}(7,812-16,21)$. For triglycerides, the average level in Bogalusa was $40 \mathrm{mg} / \mathrm{dl}$ as compared to published mean values ranging from $32-42 \mathrm{mg} / \mathrm{dl}(7,12,14-16,21)$. Cord blood lipoprotein levels have not been studied extensively but their characterization is obviously important. In the Bogalusa newborns, the mean values of $\beta$-, pre- $\beta$, and $\alpha$-lipoprotein-cholesterol were $30 \mathrm{mg} / \mathrm{dl}, 4 \mathrm{mg} / \mathrm{dl}$, and $36 \mathrm{mg} / \mathrm{dl}$, respectively, which compare closely with other reported values $(10,12-14,21)$.

Our observation that the average level of total cholesterol at birth is higher in whites than in blacks is opposite that reported in school-aged children $(11,22)$. White newborns have higher levels of total cholesterol and $\beta$-lipoprotein than black newborns. On the other hand, black Bogalusa children at school age have higher levels of total cholesterol than white children, mainly because of higher levels of $\alpha$-lipoproteins. The mean levels of $\beta$-lipoproteins are essentially the same (27). The observed black-white difference in total cholesterol and $\beta$-lipoproteins at birth persisted even when comparing newborns of the same weight or socioeconomic status. Whether the relatively greater increase in total cholesterol and $\alpha$ lipoprotein in blacks as compared to whites between birth and school age is due to the effects of environmental or other factors is not known.

The proportion of total cholesterol carried in either $\alpha-$ or $\beta$ lipoproteins is considerably different at birth than during adulthood. In contrast to Framingham adults (aged 50-59) where $21 \%$ of the total cholesterol is in $\alpha$-lipoproteins and $66 \%$ in $\beta$-lipoproteins (6), the cholesterol at birth is almost equally distributed in $\beta$ - and $\alpha$-lipoproteins. The shifting of these proportions helps explain why, at birth, total cholesterol is highly correlated with both $\beta$ - and $\alpha$-lipoproteins (Table 3 ) whereas, during adulthood, the correlation of total cholesterol is high with $\beta$-lipoproteins but nearly nonexistent with $\alpha$-lipoproteins (29). It is of interest to note that the positive correlations of cholesterol with $\beta$-lipoprotein and triglycerides with pre- $\beta$-lipoprotein and the negative correlation of triglycerides with $\alpha$-lipoproteins are observed in adults (6), school-aged children (27), preschool children (3), and newborns, suggesting that basic biochemical relationships between the lipids and lipoprotein are already established at birth.

Several investigators have recently focused on the elevating effect that perinatal stress has on cord blood triglyceride levels (2, 7,30 ). We did not detect such a relationship in Bogalusa neonates. For those 12 newborns who had a 1-min Apgar score equal to or less than 6 , only 1 had a triglyceride level at or above the 90th percentile. The difference between our study and the other three investigations may be real or it may be due to the small sample size or an undefined bias in our definition of stress. All our physical diagnoses at birth were made by Bogalusa physicians who volunteered to assist us with our program. No attempt was made to standardize their conventional approach to obstetric deliveries other than to insure that cord blood was collected in a uniform manner.

Numerous studies have focused on the utility of cord blood as a screening mechanism for identifying neonatal type II hyperlipoproteinemias $(8,13,15,16,21,23,29,31)$. Familial hypercholesterolemia (monogenic inheritance, $0.4 \%$ of all births (29) can be identified at birth if one or more parents exhibits the trait $(21$, 31 ). However, the evidence is not clear for the remaining $99 \%$ of the general population as to the value of lipids and lipoproteins at birth for predicting levels in the same individual later in life.

Several investigators have reported that cord blood cholesterol levels appear to have little relation to levels at 1 year of age $(8,16$, $23)$, whereas others suggest the evidence is far from conclusive ( 21 , $29,31)$. Kwiterovich (20) feels that cord blood $\beta$-lipoprotein cholesterol (or low density lipoprotein cholesterol) has greater diagnostic power of subsequent hyperlipidemia than total cholesterol due to the prominent contribution made to cord blood cholesterol by $\alpha$-lipoproteins. Ose (23), however, did not find this to be the case when he compared at 1 year of age, 42 infants with low density lipoprotein cholesterol levels at birth equal to or above the 95th percentile with a control group of 39 infants with cord blood values below the 95 th percentile and found no differences between the two groups of 1-year olds in either total cholesterol or triglycerides. Tsang and his associates (31) have emphasized that cholesterol levels at 1 year of age are highly dependent on diet, a factor which may alter any potential relationships between cord blood cholesterol levels and concentrations 1 year later.

Is it important to measure lipid and lipoprotein levels at birth? We feel that the lipid and lipoprotein levels in cord blood provide 
baseline data for evaluating the evolution of lipoprotein profiles in children. By far, the most dramatic change in the lipids and lipoproteins over the life span of an individual occurs during the first year of life and essentially approaches young adult levels by 2-3 years of age (3). For example, between birth and 2 years of age (based on our previous study of preschool children in the same community (3)), total cholesterol has increased by $129 \%$, triglycerides by $68 \%, \beta$-lipoproteins by $212 \%$, pre- $\beta$-lipoproteins by $81 \%$, and $\alpha$-lipoproteins by $64 \%$. If we can elucidate those factors which serve as determinants of lipid and lipoprotein levels during the first years or life, we may come closer to understanding the lipid regulatory mechanisms in the general population and thereby provide the necessary insight for programs aimed at the primary prevention of cardiovascular disease.

A longitudinal study of these children is now in progress with examinations (lipids and lipoproteins, diet, blood pressure, anthropometric measurements) at selected intervals from birth through 5 years of age.

\section{REFERENCES AND NOTES}

1. Abell, L. L., Levy, B. B., Brodie, B. B., and Kendall, F. E.: A simplified method for estimation of total cholesterol in serum and demonstration of its specificity. J. Biol. Chem., 195: 357 (1952)

2. Andersen, G. E., and Friis-Hansen, B.: Neonatal hypertriglyceridemia. Acta Paediat. Scand., 65: 369 (1976).

3. Berenson, G. S., Foster, T. A., Frank, G. C., Frerichs, R. R., Srinivasan, S. R. Voors, A. W., and Webber, L. S.: Cardiovascular disease risk factor variables at the preschool age-The Bogalusa Heart Study. Circulation, 57: 603 (1978)

4. Berenson, G. S., Srinivasan, S. R., Radhakrishnamurthy, B., and Dalferes, E. R. Jr.: Simplified primary screening procedure for detection of hyperlipidemia in healthy individuals. Clin. Chem., 18: 1463 (1972).

5. Carlson, L. A., and Hardell, L. I.: Sex differences in serum lipids and lipoproteins at birth. Eur. J. Clin. Invest., 7: 133 (1977).

6. Castelli, W. P., Cooper, G. R., Doyle, J. T., Garcia-Palmieri, M., Gordon, T. Hames, C., Hulley, S. B., Kagan, A., Kuchmak, M., McGee, D., and Vicic, W. J.: Distribution of triglycerides and total, LDL and HDL cholesterol in several populations: A cooperative lipoprotein phenotyping study. J. Chron. Dis., 30: 147 (1977).

7. Cress, H. R., Shaher, R. M., Laffin, R., and Karpowicz, K.: Cord blood hyperlipoproteinemia and perinatal stress. Pediat. Res., 11: 19 (1977).

8. Darmady, J. M., Fosbrooke, A. S., and Lloyd, J. K.: Prospective study of serum cholesterol levels during first year of life. Brit. Med. J., 2: 685 (1972).

9. Department of Health, Education and Welfare. Manual of laboratory operations, Lipid Research Clinics program, Vol. 1: Lipid and lipoprotein analysis. Publication no. (NIH) 75-628 (1974).

10. Dyerberg, J., Hjorne. N., Nymand, G., and Olsen, J. S.: Reference values for cord blood lipid and lipoprotein concentrations. Acta Paediat. Scand., 63: 431 (1974).

11. Frerichs, R. R., Srinivasan, S. R., Webber, L. S., and Berenson, G. S.: Serum cholesterol and triglyceride levels in 3.446 children from a biracial community-The Bogalusa Heart Study. Circulation, 54: 302 (1976).

12. Glueck, C. J., Gartside, P. S. Tsang, R. C., Mellies, M., and Steiner, P. M.: Blackwhite similarities in cord blood lipids and lipoproteins: A preliminary report. Metabolism, 26: 347 (1977)

13. Glueck, C. J., Heckman, F.. Schoenfeld, M., Steiner, P., Pearce, W.: Neonatal familial Type II hyperlipoproteinemia: Cord blood cholesterol in 1,800 births. Metabolism, 20: 597 (1971)
14. Glueck, C. J., Steiner, P., and Leuba, V.: Cord-blood low-density lipoprotein cholesterol: Estimation versus measurement with the preparative ultracentrifuge. J. Lab. Clin. Med., 82: 467 (1973).

15. Goldstein, J. L., Albers, J. J., Schrott, H. G., Hazzard, W. R., Bierman, E. L., and Motulsky, A. G.: Plasma lipid levels and coronary heart disease in adult relatives of newborns with normal and elevated cord blood lipids. Amer. J. Hum. Genet., 26: 727 (1974).

16. Greten, H., Wengeler, H., and Wagner, H.: Early diagnosis of familial Type II hyperlipoproteinemia. Nutr. Metabol., 15: 128 (1973).

17. Holman, P. L., McGill, H. C., Strong, J. P., and Geer, J. C.: The natural history of atherosclerosis: The early aortic lesions as seen in New Orleans in the middle of the 20th century. Amer. J. Pathol., 34: 209 (1958).

18. Kannel, W. B., Castelli, W. P., Gordon, T., and McNamara, P. M.: Serum cholesterol, lipoproteins, and the risk for coronary heart disease. The Framingham Study. Ann. Intern. Med., 74: 1 (1971).

19. Keys, A.: Coronary heart disease-The global picture. Atherosclerosis 22: 149 (1975)

20. Kwiterovich, P. O.: Neonatal screening for hyperlipidemia. Pediatrics, 53: 455 (1974)

21. Kwiterovich, Jr., P. O., Levy, R. I., and Fredrickson, D. S.: Neonatal diagnosis of familial Type II hyperlipoproteinemia. Lancet, $i$ : 118 (1973).

22. Levy, P. S., Hamill, P. V. V., Heald, F., and Rowland, M.: Total serum cholesterol values of youths 12-17 years. Vital Health Statistics, Series 11, No. 156, May (1976).

23. Ose, L.: LDL and total cholesterol in cord-blood screening for familial hypercholesterolemia. Lancet, ii: 615 (1975).

24. Snedecor, G. W., and Cochran, W. G.: Statistical Methods (Iowa State University Press, Ames, lowa, 1967).

25. Spellacy, W. N., Ashbacher, L. V., Harris, G. K., and Buhi, W. C.: Total cholesterol content in maternal and umbilical vessels in term pregnancies. Obstet. Gynecol., 44: 661 (1974).

26. Srinivasan, S. R., Frerichs, R. R., and Berenson, G. S.: Serum lipid and lipoprotein profile in school children from a rural community. Clin. Chim. Acta, 60: 293 (1975).

27. Srinivasan, S. R., Frerichs, R. R., Webber, L. S., and Berenson, G. S.: Serum lipoprotein profile in children from a biracial community-The Bogalusa Heart Study. Circulation, 54: 309 (1976).

28. Strong, J. P., Eggen, D. A., Oalmann, M. C., Richards, M. L., and Tracy, R. E. Pathology and epidemiology of atherosclerosis. J. Amer. Diet. Assoc., 62: 262 (1972).

29. Tsang, R. C., Fallat, R. W., and Glueck, C. J.: Cholesterol at birth and age 1: Comparison of normal and hypercholesterolemic neonates. Pediatrics, 53: 458 (1974).

30. Tsang, R., Glueck, C. J., Evans, G., and Steiner, P. M.: Cord blood hypertriglyceridemia. Amer. J. Dis. Child. 127: 78 (1974).

31. Tsang, R. C., Glueck, C. J., Fallat, R. W., and Mellies, M.: Neonatal familial hypercholesterolemia. Amer. J. Dis. Child. 129: 83 (1975).

32. Tyroler, H. A., Hames, C. G., Krishan, I., Heyden, S., Cooper, G., and Cassel, J. C.: Black-white differences in serum lipids and lipoproteins in Evans County. Prev. Med., 4: 541 (1975).

33. The authors are grateful to Drs. A. R. Singleton, Jr., and V. G. Waldrup of Bogalusa for their invaluable cooperation and assistance, to the nursing staffs of Bogalusa Medical Center and Washington- St. Tammany Charity Hospital for their technical support, and the staff of the Bogalusa Heart Study, without whom the study would not have been possible.

34. This research was supported by funds from the National Heart, Lung and Blood Institute of the USPHS, Specialized Center of Research-Arteriosclerosis (SCOR-A) HL15103.

35. Requests for reprints should be addressed to: Gerald S. Berenson, M.D., Department of Medicine, L.S.U. Medical Center, 1542 Tulane Avenue, New Orleans, LA 70112 (USA).

36. Received for publication September 15, 1977

37. Accepted for publication November 2, 1977. 